\title{
The effect of mining foreign direct investment inflow on the economic growth of Zimbabwe
}

\author{
Plaxedes Gochero ${ }^{1 *}$ (D) and Seetanah Boopen ${ }^{2}$
}

\author{
*Correspondence: \\ gocheroplaxedes@gmail.com \\ ${ }^{1}$ Open University \\ of Mauritius, Reduit, Moka, \\ Mauritius \\ Full list of author information \\ is available at the end of the \\ article
}

\begin{abstract}
The study employs the autoregressive distributed lag (ARDL) approach to examine the relationship between foreign direct investment (FDI) in the mining sector on the Zimbabwe economy, while controlling for both non-mining FDI and domestic investment. Using data over the period 1988-2018, this research results show that foreign direct investment in the mining sector has a significant positive relationship with the country's GDP in the long run. Mining FDI is revealed to have relatively higher effects as compared to FDI in non-mining sector and domestic investment. The short-run analysis observed that mining FDI as well as non-mining and domestic investment still has positive and significant impacts on growth but at a relatively lower extent. This implies that it takes some time for such investments to have their full effect on the economy.
\end{abstract}

Keywords: Foreign direct investment inflow, The Zimbabwean mining sector

\section{Introduction}

Foreign direct investment (FDI) is crucial for developing nations like Zimbabwe. It is very important for industrial development because it provides a unique combination of long-term finance, technology, training, technical know-how, managerial expertise and marketing experience. According to Hill (2011), it is a way of exploiting long-term profit opportunities in a foreign market apart from exporting and licensing. In direct investment, the investor participates in the control and management of such business venture which is outside the investor's country (Dunning and Lundan 2008).Foreign firms set up plants to supply the host country`s market as well as the host nation`s neighboring countries. Foreign firms can also invest in other countries for the sake of supply chain control (Demirhan and Masca 2008). Manufacturing companies have a great desire to control the flow of material from suppliers, through the value-adding processes and distribution channels, to customers. FDI creates an opportunity for developing countries to reduce dependence on foreign aid which helps in boosting sovereignty against donor policies. However, FDI may also have a negative effect which is the reason why some governments of developed countries prefer free movement of capital and put efforts on restricting the entrance of foreign investment (Zilinske 2010). These negative effects

(c) The Author(s) 2020. This article is licensed under a Creative Commons Attribution 4.0 International License, which permits use, sharing adaptation, distribution and reproduction in any medium or format, as long as you give appropriate credit to the original author(s) and the source, provide a link to the Creative Commons licence, and indicate if changes were made. The images or other third party material in this article are included in the article's Creative Commons licence, unless indicated otherwise in a credit line to the material. If material is not included in the article's Creative Commons licence and your intended use is not permitted by statutory regulation or exceeds the permitted use, you will need to obtain permission directly from the copyright holder. To view a copy of this licence, visit http://creativeco mmons.org/licenses/by/4.0/. 
include increased financial risks, foreign exchange rates crises, transfers of obsolete and dirt technologies which are suffered by developing countries (Djokoto and Dzeha 2012).

African governments have tried to develop policies that encourage inward FDI flows. Despite efforts by African governments, FDI flows to the continent continue to decline. United Nations Conference on Trade and Development (UNCTAD) World Investment Report (World Investment Report 2017) states that FDI flows to Africa fell by 3 percent from $\$ 61$ billion in 2015 to $\$ 59$ billion in 2016, but with variance across regions and countries. This overall decline of FDI flows to Africa is largely a result of weak commodity prices. In Africa, many developing countries had targeted 2015 as the year by which the millennium development goals (MDGs) were to have been achieved; however, most developing countries across Sub-Saharan Africa have missed the target leaving them desperate for significant levels of foreign investments for them to restore their earlier economic status. The belief is that most of these developing countries are lagging behind for the simple reason of not having adequate resources to finance long-term investments which is a huge setback to economic growth (United Nations, MDGs Report 2015).

Growth effects of FDI differ from country to country because of economic, political and social differences across these developing countries. Zimbabwe ${ }^{1}$ like other developing countries in Africa has received FDI for its development and is still striving to attract this important resource flow. It is a fact that Zimbabwe has experienced serious shortages domestic investment to fund critical inputs in the various growth inducing sectors of the economy, mining sector included during the past decades, and it is believed that FDI has been of critical support to the economy. This implies that receiving foreign capital and investment enables Zimbabwe to make investments in human and physical capital as well as exploitation of opportunities that otherwise could not be used for development.

It is noteworthy that since independence in 1980 and till 1991, the government of Zimbabwe was quite defensive vis-a-vis foreign investment, and each proposal was subjected to careful scrutiny and foreign investors were required to get permission from the Foreign Investment Center for the development of any new enterprise in the country. In 1991, although there was some revisions of those regulations, the emphasis on indigenization still remained strong. Political turbulence and the government's defiance of the IMF in the late 1990s increased investor risk significantly and subsequently, foreign direct investment flows was brought to a standstill. Indeed, in 1998, FDI reached over $\$ 444$ million and by 2001, FDI inflow fell heavily to $\$ 5.4$ million. FDI flows recovered since 2008 due to the so-called process of economic normalization and the enhancement of the country's business climate, although FDI remained far under their potential. In 2018, total FDI stock stood at USD 5.4 billion and represented $20.8 \%$ of the GDP. The FDI inflows increased significantly to USD 745 million in 2018, compared to pre-crisis period and 2017 (USD 349 million), according to the UNCTAD's 2019 World Investment Report. Interesting to note from this report is the fact that FDI is currently mainly

\footnotetext{
${ }^{1}$ Due to a long drought, Zimbabwe's economy slowed down in 2016, but it recovered in 2017 (2,8\% of GDP) thanks to exceptional agriculture returns. In 2018, the economy performed better than expected, recording a 3.5\% GDP growth, driven by agriculture, supported by relatively peaceful elections. For the next couple of years, growth is expected to increase and reach $4.2 \%$ in 2019 and $4.7 \%$ in 2020
} 
in the mining sector, ${ }^{2}$ infrastructure, the wood industry healthcare, water and sanitation, financial services, tourism, manufacturing, and agriculture. China is the first investor in Zimbabwe. Russia, Iran and India are also important investors in the country.

The mining sector of Zimbabwe's remains a key driver of sustainable economic development. Indeed, this sector contributes a lot to exports as well as having crucial interlinkages with other sectors of the economy. FDI in the mining sector is critical for carrying out mineral exploration, extraction, processing and marketing because Zimbabwe lacks enough capital and technological resources to finance such capital intensive large-scale projects (Chimuka 2007). It is noteworthy that in 2017, the sector contributed about $10 \%$ to GDP and $60 \%$ of exports which is a very significant contribution to GDP (Government of Zimbabwe 2017).

This study, thus, aims atexamining the effect of foreign direct investment inflows in the Zimbabwean mining sector on country's economic performance over the period 19882018. It also takes into account FDI in non-mining sector and domestic investment, providing additional comparative insights. The research employs dynamic time series regression, namely an ARDL framework to model the dynamic FDI-growth nexus, while also analyses both the short- and long-run growth effects of mining FDI.

The rest of the paper is organized as follows: Sect. 2 provides a brief review of the literature, Sect. 3 dwells into the methodology and analyses the results of the regression estimates while Sect. 4 concludes.

\section{Literature review}

2.1 Theoretical literature on effects of foreign direct investment on host country in general FDI has grown both in relation to trade and in absolute terms in the last two decades due to globalization (World Economic Forum 2013). It is very important because it is a major source of external finance that enables countries with limited amounts of capital like developing countries to benefit by receiving funds from wealthier countries. It is important in transferring skills and technology from the developed countries to host countries (Berger and Diez 2008). However, the effect of FDI on transfer of technologies and skills has been inconclusive although it is believed to be sources of technology transfers found in different parts of the world (Ford et al. 2008). FDI is regarded a superior source of capital because of its lasting prospects as well as multiple purposes when compared to other private capital sources. It has become the largest component of net resource flows to developing countries since 1994. Adding to the provision of new capital, there are many channels through which FDI can boost growth rates for example FDI is accepted as a means to incorporate new knowledge from abroad. This new knowledge is beneficial to host country as they imitate, learn and increase competition in local market. Theory of the TNCs states that multinational corporations have technology advantages over local firms that outweigh the cost of doing business in external markets (Rugraff and Hansen 2011). It offers a long-term commitment compared to other forms of financial inflows like portfolio equity flows.

\footnotetext{
${ }^{2}$ The country has a very rich natural potential (second largest reserve of platinum and chrome; diamonds, coal, gold, platinum, copper, nickel, tin). The total number of projects approved by the Zimbabwe Investment Authority for the period 2016-2018 is, respectively, 54 (USD $160 \mathrm{~m}$ ), 60(USD 577) and 135 (USD 1382).
} 
Although FDI is given credit for positive impact on human capital formation in host country, there is another side to it. Marxist political and economic theory views Trans National Corporations (TNCs) as an instrument of imperialist domination. The Marxist regard TNCs institutions bent on making profit, repatriating it to home country and these TNCS neither intend to transfer technology to host country nor play any role in employment creation (Kurtishi-Kastrati 2013). TNCs could bring obsolete and dirty technology was the argument of Djokoto (2012). Outdated obsolete machinery would be inefficient and finding spare parts for such machinery would be difficult. Further, dirt technologies contribute significantly to environmental pollution and degradation leading to unsustainable development, hence defeating the initial purpose of the move that is to attract FDI (Chamber of Mines 2009).

According to Mencinger (2008), TNCs sometimes hinder the growth of indigenous firms and monopolize markets because they are more powerful. While initial effects of FDI on host countries balance of payment are usually positive in the long run, balance of payment is negatively affected because of subsequent outflow of earnings and divestments as well as increased imports of intermediate goods and services. To control this, some countries restrict or limit profit repatriation by imposing taxes and sanctions.

The extent to which foreign owned firms borrow from domestic market reduces the benefits of FDI (Salvatore 2007). Foreign firms borrow from domestic market resulting in crowding out of local domestic investment as a result of increased interest rates. This increases the risk of repatriation of funds borrowed (İpek and Kizilgöl 2015). Negative effects of excessive borrowing are that the venture becomes more risky ending up with host country and not the TNC carrying the risk of the venture (Salvatore 2007). This situation can result in the TNC getting easier exit in difficult times in which case FDI is made more foot loose. FDI could bring inappropriate resources, assets and practice to host country. TNCs also affect industry relations negatively and could own or even undermine the sovereignty of the host country.

Most literature promotes the idea that FDI is beneficial to host countries (for example, Moura 2010). Developing countries are encouraged to try and acquire FDI and portfolio equity inflows to stimulate long-term growth chances rather than limit themselves to national savings (World Bank 2017). As a result, many governments have encouraged FDI inflows and try as much as possible to give incentives. This shows that the general belief is that the positives outweigh the negatives when developing countries such as Zimbabwe decide on FDI issues. Moreover, despite the contradictory arguments, the need for FDI is rising gradually. Country level and cross country studies have come up with mixed findings on the effects of FDI on host country and cannot be generalized from country to country or region to region. This impact is a function of many factors like microeconomic environment, political stability and many other factors (Moura and Forte 2013).

Benefits of foreign direct investments in host country also include enhancement of competitive business contribution to international trade integration and improvement of enterprise development (Kastrati 2013; Alfaro 2017). Apart from economic benefits, FDI is beneficial to host country by improving the environment and social condition in the host country through bringing in/relocating cleaner technology as well as guiding the host country to more socially responsible cooperate policies. These benefits 
contribute to economic growth which leads to the alleviation of poverty in these host economies, Alfaro (2017). Measuring with accuracy, the economic effects of FDI are not an easy task since benefits vary from country to country, and hence difficult to separate and measure. In most cases, the assessment of the development effects of FDI is done following two approaches, econometric analysis of the relationship between inward FDI and the numerous aspects of TNCs impacts or qualitative analysis of the various aspects of TNCs effects (UNCTAD 2009).

There is a group of theories that provide the rationale of the effect of FDI on economic growth called the FDI nexus (Helphman and Grossman 1991). An example is that the modern endogenous growth theory shows that long-run economic growth of an economy can result from more open liberalized government policies conducive for FDI inflows. Capital highly increases returns to scale such that changes in FDI inflows can be an important means for long-run economic growth in developing countries. The other group of theories attempts to relate theoretical consideration to the impact of FDI on the environment in developing countries. This group is known as the FDI environment nexus (Copeland and Taylor 1994; Porter and Van der Linde 1995). Examples are the pollution haven model [Copeland and Taylor (2003) and the Porter's hypothesis, Porter and Van der Linde (1995)].

\subsection{Empirical literature on effects of foreign direct investment}

\subsubsection{Effect of FDI and host country economic growth}

Economic growth can be achieved when FDI enables employment of people, bridging the gap between savings and investments as well as taxes. Through taxes, FDI enhances capital formation for the government and also defuses balance of payment pressure; technical knowledge, advancement and qualitative improvements in labor force are also considered as important factors that contribute to economic growth (Moura and Forte 2013; Knoerich 2017). The factors that contribute towards economic growth are interdependent such that progress in one factor can facilitate advancement in another. Poor performance in one factor can hinder progress of the factors. Factors such as host country capital, human capital, technology, infrastructure, trade and productivity affect the effect of FDI on economic growth of host countries (Heliso 2014).

Although FDI affects host country's economic growth, it seems that developing countries need to gain a certain level of development in education and or infrastructure to be able to reap the potential benefits that come through FDI. Studies (Heliso 2014)have proved that certain conditions have to be met for the positive effects to be experienced. These conditions or factors include, for example, the levels of human capital, levels of education, trade openness in the host country as well as the ability to absorb technology by the host country as already mentioned (Noormamode 2008; Solomon 2011). Earlier studies by Khan (2007) found that the same amount of increase in FDI generated three times more additional growth in financially well-developed host countries than countries that are poorly developed in terms of finance. Alfaro et al. (2007) contributed to existing literature that emphasizes how local policies and institutions may actually limit the potential benefits that FDI could promote to a host country. They concluded that, local conditions such as the development of financial markets and educational level of the country affects the impact of FDI on economic growth. They also recommended that 
policy makers should exercise caution when trying to attract FDI that is complimentary to local production.

The issue of technology has also been emphasized (Berger and Diez 2008). The smaller the technology gaps between the host and the home country, the larger the impact of FDI on economic growth. This implies that countries that are less technologically advanced may, therefore, have a limited FDI impact on economic growth (OECD 2002). Technology is important especially for small countries that rely on export performance in order for them to improve their export composition. The strength of export performance to a large extent depends on technology (Sandua and Ciocanelb 2014). Apart from promoting host country's growth through production of new/advancement technology, FDI also enables the host country to have a greater output from any combination of input (OECD 2002).

Empirical studies examining the FDI-Growth nexus, using different data and methodologies, have found that FDI tends to have positive impacts on economic growth (Koojaroenprasit, 2012; Melnyk et al. 2014; Muntah et al. 2015; among others).Other studies came up with contrasting results to the effect that FDI tends to have non-significant or even negative impacts on economic growth in host countries (Javorcik 2004; Ruranga and Kaberuka 2013). Studies on developed countries show positive effects in general, yet those on developing countries are usually inconsistent producing positive effects, negative effects or no effects (Beugelsdijk et al. 2008; Demissie, 2015).

Noy and Vu (2007) applied sectorial FDI inflow data to evaluate the sector-specific impact of FDI on growth. The results exhibited that, for the two developing transitions economies China and Vietnam, FDI has a positive statistically significant effect on economic growth operating directly and indirectly through its interaction with labor in those sectors. The results were different across economic sectors with almost all beneficial impact limited to industrial sector. The other sectors appeared to gain little from the sector-specific FDI and mining was concluded to be the least beneficiary. As argued by Fortainer (2003), the determinants and effects of such FDI need to be contextualized. Indeed, results provided by Noy and Vu (2007) are arguably results from a country with low to zero diamonds which is not anywhere close to Zimbabwe which apart from having 38 other minerals claims to have a quarter of the world's germ and to be the third largest producer of platinum following South Africa and Russia, hence the need to seek a deeper insight into this debate.

Alfaro et al. $(2007,2016)$ and Fasanya (2012) recommended that, for countries to effectively reap the benefits of FDI, there is a need for proper economic planning that creates a health and enabling business environment to encourage both foreign and local investors. Providing incentives for innovation and skills improvement that contributes to competitive corporate climate has been proposed by most of the scholars who have studied FDI and economic growth in any way. However, what most of them did not address is, which sector these policies should target a question that has been attempted by a few researchers (Vu et al. 2006; Khaliq and Noy 2007).

Khaliq and Noy (2007) studied the impact of FDI on economic growth in Indonesia in different sectors using FDI data from 1997 to 2006. Although the study concluded that at aggregate level, FDI does have a positive effect on the economic growth, at sectorial level, the effects of FDI and economic growth vary across sectors and have no aggregate 
effects. They also made similar observations to those of Noy and Vu (2007), in that FDI in the mining sector had negative effects on the economic growth. These results confirmed the argument that extractive FDI might not enhance economic growth by $\mathrm{Vu}$, et al. (2006) bringing doubt to the expected general benefits of FDI inflows.

Moyo (2013) studied the determinants of FDI in the post dollarization period of 20092012 using monthly data. The author used a multiple regression model that linked FDI as well as other macroeconomic variables such as government expenditure and private saving to gross domestic product. It should also be noted that the study was based only on macro-FDI data. That data were based on the whole nation and not sectors which is the scope of this study. The study concluded that FDI foreign direct investment had a significant positive impact on economic growth in the country.

There are models which suggest that FDI leads to promotion of economic growth only under certain conditions. Moura and Forte (2013) study concluded that the effects of FDI on economic growth are dependent on existing or subsequently developed internal conditions of the host country's economic, political, social, and cultural which is in line with the eclectic theory of Dunning (1993). They maintain that local authorities have a role to play to achieve the desired effects and it is the governments that should design policies that are appropriate for a country to enjoy the positive effects of FDI and mitigate the negative effects. Moura and Forte (2013) argues that the local authorities have to be proactive about attracting and directing FDI if the various sectors of the economy are to benefit from it, a contribution which was different from those by other scholars mentioned earlier.

Hong (2014) employed GMM to re-evaluate the effect of FDI on the economic growth in China and the relevant factor of FDI during the period 1994-2010, based on dynamic panel data from 254 prefecture-level cities in China. The results were that FDI exert positive impact on the economic development. It was further reported that economies of scale, human capital, infrastructure level, wage levels, regional differences interact actively with FDI and promote economic growth in China, while the openness of trade does not induce FDI significantly. Hong (2014) also concluded that it is likely that FDI has crowded out the domestic capital and left the domestic capital and huge foreign exchange reserves with the problem of rational usage. Maliwa and Nyambe (2015) subsequently studied the impact of FDI on economic growth in Zambia. They used data from World Bank development indicators 1980-2012. The findings were that FDI does not granger cause economic growth in Zambia. The implication was that unless the Zambian government considers reforming policies, FDI will not serve as the prelude for the desired economic growth.

Zekarias (2016) analyzed the impact of FDI on Economic growth in 14 Eastern Africa countries by employing 34 years (1980-2013) panel data, using dynamic GMM estimators after checking for autocorrelation and model specification tests. The findings confirm that FDI is a key deriver of economic growth and a catalyst to economic conditional convergence in Eastern Africa; so, the sub-region needs to attract more FDI by improving investment environment, strengthening regional integration, developing human capital and basic infrastructure, and promoting export-oriented investment. Bakari (2017) also investigated the relationship between domestic investment and economic growth in Malaysia. Annual data for the periods between 1960 and 2015 were tested using 
Correlation analysis, Johansen cointegration analysis of Vector Error Correction Model and the Granger-Causality tests. Result of the analysis proved that there is a positive effect of domestic investment, exports and labors on economic growth in the long run; however, there is no relationship between domestic investment and economic growth in the short-run term.

A summary of the literature shows that not much empirical studies have been carried out on the effects of sectorial, particularly for the mining sector, foreign direct investment inflow on the economic growth. Neglecting sectorial studies on effects of FDI might be the explanation as to why some economies are yet to reap the full fruits of FDI. Moreover, existing studies have in general ignored the issue of dynamism, an element which remain crucial in the FDI-growth modeling.

\section{Methodology and analysis}

\subsection{Conceptual framework}

The conceptual framework is based on an augmented Cobb Douglas model rooted in the endogenous growth theory. Indeed, from the basic Cobb Douglas model, the output level of the country is dependent on capital and labor. The capital component in our case is broken down into domestic and FDI, with FDI further segregated into Mining and Non-mining FDI, allowing us to estimate the effect of Mining FDI which is of interest to this study. Moreover, the Cobb Douglas model is extended to include a few other determining factors of growth such as education, openness level and financial development. Similar approach has been used by Khadaroo and Seetanah (2008), Moura and Forte (2013), Seetanah and Teeroovengaum (2019) in their studies of economic growth. It is to be noted that the focal point for this study is to assess the effect of FDI in the mining industry on the country's growth.

Capital is, thus, disaggregated into domestic and FDI in the first instance, and subsequently FDI is decoupled into mining and non-mining capital. The resulting production specification is:

$$
Y_{t}=A_{t}\left(K_{t}\right)^{\beta 1}\left(F D I M_{t}\right)^{\beta 2}\left(\mathrm{FDINM}_{t}\right)^{\beta 3}\left(L_{t}\right)^{\beta 4} .
$$

The Cobb-Douglas function is both homothetic and strongly separable.

$\mathrm{Y}$ denotes the economy's output, $A$ is the shift in the production function attributed to technical progress, which is assumed to be risk neutral, $\mathrm{K}$ is the domestic investment, $\mathrm{L}$ is labor, FDIM is the FDI in the mining sector, and FDINM is the FDI in the nonmining. In such a set-up, an increase in this capital raises output through its positive effect on the marginal productivity of capital and labor. The importance of FDI has been discussed earlier in the paper.

The Cobb-Douglas production function has a number of convenient properties. The parameters of the explanatory variables measure the elasticities of output. The parameter A may be regarded as an efficiency parameter, since for fixed inputs $\mathrm{K}$ and $\mathrm{L}$, the larger is $\mathrm{A}$, the greater is the maximum output obtainable from such inputs.

Equation (1) is linearized by applying natural logarithm on both sides. By allowing a stochastic disturbance term to enter the production technology, the following log-linear regression equation is obtained from Eq. (2). 


$$
y_{t}=\alpha+\beta_{1}\left(k_{t}\right)+\beta_{2} f \operatorname{dim}_{t}+\beta_{3} \mathrm{fdinm}_{t}+\beta_{4} l_{t}+\mu_{t} .
$$

We further extended the above to include trade openness (TO) and financial development (FD) since they are crucial growth ingredient for the country. Trade openness of the country is included in the economic model following the work of Dollar (1992), Sachs and Warner (1995) and more recently Burange et al. (2019). These authors supported the idea that increased trade openness raised economic growth through access for a country to the advances of technological knowledge of its trade partners, access bigger markets and encouraging the development of R\&D through increasing returns to innovation and also through providing developing countries with access to investment and intermediate goods that are vital to their development processes. Finally, we added a measure of financial development (FD) McKinnon (1973). And King and Levine (1993) argued that financial development, through its critical function of enhancing the efficiency of intermediation namely by reducing information, transaction, and monitoring costs might lead to economic growth. As such Creane et al. (2003) posited that a modern and efficient financial system mobilizes savings, promotes investment by identifying and funding good business opportunities, monitors the performance of managers, enables the trading, hedging, and diversification of risk, and facilitates the exchange of goods and services. These functions ultimately result in a more efficient allocation of resources, a more rapid accumulation of human and physical capital, and a faster technological progress, which in turn feed economic growth A strong consensus has emerged in the last decade that well-functioning financial intermediaries have a significant impact on economic growth ${ }^{3}$ (see King and Levine 1993; Rajan and Zingales 1998; Levine et al. 2000; Seetanah et al. 2009; Guru and Yadav 2019).

The lowercase variables are the natural log of the respective uppercase variable. Thus, the extended model is as follows

$$
\mathrm{y}_{\mathrm{t}}=\alpha+\beta_{1} \mathrm{k}_{\mathrm{t}}+\beta_{2} \mathrm{fdim}_{\mathrm{t}}+\beta_{3} \mathrm{fdinm}_{\mathrm{t}}+\beta_{4} \mathrm{l}_{\mathrm{t}}+\beta_{5} \mathrm{ol}_{\mathrm{t}}+\beta_{6} \mathrm{fd}_{\mathrm{t}} \mu_{\mathrm{t}} .
$$

The disturbance term $\mu_{t}$ is a deviation from the production function relationship. When the output and inputs time series are unit root processes but the disturbance term is a stationary process, equation above becomes a cointegrating relation implying a longrun relationship between output, private capital, transport capital, non-transport capital, and labor. The slope coefficients $\beta_{1, \ldots .} B_{6}$ are then interpreted as long-run elasticities and are greater than zero.

\subsection{Measurement of variables}

The dependent variable is the Gross Domestic Product ( $Y)$, a proxy for national output, while the independent variables are summarized in Table 1.

Data are collected from various sources in the country including Zimbabwe Investment Authority (ZIA), Ministry of Mines and Mining Development, Reserve Bank of

\footnotetext{
${ }^{3}$ It is noteworthy that recent studies by Arcand et al. (2015) and Samargandi et al. (2015) showed that the relationship between financial development and growth could be nonlinear with an inverted U-shaped (or Kuznets curve). This indicates that financial development can enhance economic growth up to a certain point, but if it goes the threshold level, economic growth would be dampened. Arcand et al. (2015) referred to this negative effect of Nonlinearity as the 'vanishing effect'.
} 
Table 1 Summary of variables

\begin{tabular}{|c|c|c|}
\hline Variable & Proxy & Supporting Literature \\
\hline Labor $(\mathrm{L})$ & $\begin{array}{l}\text { National literate rate from ordinary } \\
\text { level passes }\end{array}$ & $\begin{array}{l}\text { Khadaroo and Seetanah (2008), } \\
\text { Seetanah and Teeroovengadum } \\
\text { (2019) }\end{array}$ \\
\hline Financial Sector Development (FD) & $\begin{array}{l}\text { Measured as the ratio of private sec- } \\
\text { tor credit to GDP }\end{array}$ & $\begin{array}{l}\text { King and Levine (1993), Seetanah } \\
\text { et al. (2009), Guru and Yadav } \\
\text { (2019) }\end{array}$ \\
\hline Openness Level (OL) & Measured by $(X+M / G D P)$ & $\begin{array}{l}\text { Dollar (1992), Warner (1995), Khada- } \\
\text { roo and Seetanah (2009) }\end{array}$ \\
\hline Domestic Investment Level (K) & $\begin{array}{l}\text { Measured by national level of capital } \\
\text { formation (the ratio of GDFCF to } \\
\text { GDP) }\end{array}$ & Bakari (2017), Zekarias (2016) \\
\hline FDI in the mining sector (FDIM) & $\begin{array}{l}\text { Measured as the amount of FDI } \\
\text { flows to the mining sector as a } \\
\text { ratio of GDPData on mining sector } \\
\text { FDI has been obtained from Zim- } \\
\text { babwe Investment Authority (ZIA) }\end{array}$ & $\begin{array}{l}\text { Khadaroo and Seetanah (2008), } \\
\text { Fauzel et al. (2018) }\end{array}$ \\
\hline $\begin{array}{l}\text { FDI in the non-mining sector } \\
\text { (FDINM) }\end{array}$ & $\begin{array}{l}\text { Measured as the ratio of the non- } \\
\text { mining section to GDP (non- } \\
\text { mining sector = total FDI-FDI in } \\
\text { the mining sector) }\end{array}$ & Author derivation \\
\hline
\end{tabular}

Zimbabwe (RBZ) and Chamber of Mines and Zimbabwe National Statistics Agency (ZIMSTAT). As mentioned above, the study uses the ARDL model using data collected on 31 years that is from 1988 to $2018 .^{4}$

\subsection{Analysis of results}

\subsubsection{Unit root and cointegration tests}

It is a prerequisite to test the time series properties of every time series data to avoid spurious correlation. To check the presence of any Unit root and the level of stationarity, the Augmented Dickey Fuller (ADF) test is employed and it is noted that some of the model variables, including the dependent variable, are stationary at level; while, few others are stationary only after first differencing. Similar conclusions were reached with the Phillips-Perron test. Given the presence of both $I(0)$ and $I(1)$ variables, the ARDL is the preferred approach for the test of a long-run relationship and the estimation of the coefficients. ARDLs are standard least squares regressions that comprise lags of both the dependent variable and explanatory variables as regressors. The ARDL approach is used to analyze cointegration as a way of resolving the problem of constancy of means and variances that are not satisfied in analyzing time series variables as mentioned above. It is more desirable when working with variables that are integrated of order $I(0), I(1)$ or combination of both. It is strong when there is a single long-run relationship between the underlying variables in small sample size (Nkoro and Uko 2016). The F-statistic (Wald test) is used to detect the long-run relationship of the underlying variables in this approach. Test results from the ARDL bounds test for cointegration suggest the

\footnotetext{
${ }_{4}^{4}$ Although the authors would have wished to have more yearly observations for more reliable results, unfortunately, this is the maximum about of yearly data available and this limitation is acknowledged.
} 
Table 2 The ARDL long-run estimates [Dep variable: y(gdp)]

\begin{tabular}{lcc}
\hline Variables & Long-run Coef & $T$ values \\
\hline fdim & $0.512^{* * *}$ & 2.245 \\
fdinm & $0.323^{* * *}$ & 2.323 \\
I & $0.745^{*}$ & 1.86 \\
ol & -0.365 & -1.12 \\
k & $0.46^{* *}$ & 1.95 \\
fd & $0.26^{* *}$ & 1.97 \\
const & 1.56 & 1.256
\end{tabular}

We alternatively used GDP per capital as our dependent variable and the results obtained are consistent on the overall

* Is significance at $10 \%$; ${ }^{*}$ at $5 \%$ and ${ }^{* * *}$ at $1 \%$, respectively. Ramsey RESET test \{residual squares/functional form\}: $F=0.58$. Breusch-Pagan heteroscedasticity: Chi-square $=11.01$; Jarque-Berra Normality test: Chi-square $=4.3541$; Serial Correlation LM test: Chi-square $=3.12$

presence of cointegration among the variables of the model at the 5\% significant level $(F$-statistic $=5.45)$.

3.3.1.1 The ARDL estimates The next stage is be to estimate the coefficients of the long-run relations and the associated Error Correction Model (ECM) using the ARDL approach. The order of the distributed lag on the dependent variable was selected by the SBC and turned out to be one and the SBC criteria select the ARDL $(1,0,0,1,0,1,0)$ for the models. The selected ARDL passes the standard diagnostic tests related to functional form test (Ramsey's RESET test), normality test (Jaque-Bera test) and Serial Correlation LM test, heteroscedasticity test (Brush pagan test).

\subsection{Discussion of Estimation Results}

Results from Table 2 reveal that FDI in the mining sector (fdim) has a positive and significant impact on economic growth of the country in the long run. The estimated coefficient of 0.512, a measure of elasticity, implies that a $1 \%$ increase in FDI in the mining sector has contributed to $0.512 \%$ increase in the GDP of the Zimbabwean economy. Such result is in line with Bucaj (2018) who studied the role of FDI inflows in the Mining Sector to Kosovo's economic growth and found out that FDI in mining has a positive and significant impact on GDP per capita which was used as a proxy for growth. Bucaj (2018) reported that the coefficient for FDI in mining is positive but small suggesting a very minimal effect on GDP per capita. However, the author suggested that there was a necessity to sustain and attract further FDI in order for the economy to benefit. From the results of our study, it is also necessary to attract more FDI to further increase the GDP of the Zimbabwean economy. The study by Awolusi and Adeyeye (2016) also revealed that, in general, the impact of FDI on economic growth in African countries is limited or negligible and not automatic. It postulates that FDI tends to have a significant effect on economic growth through multiple channels like gross capital formation, human capital enhancement, technological transfer, spillovers, and labour force. The author recommends that policy makers in Africa should understand the role of incentives as these can compensate market failures to achieve economic and social objectives. The author recommended that relevant countries should try to attract FDI in the mining sector. Our 
results also corroborate to a large extent with that of Moyo (2013) for the case of Zimbabwe. The author reported that aggregate FDI had a very significant impact on economic growth in Zimbabwe, using a multiple regression model. Zekarias (2016) also found a positive correlation between FDI and economic growth concluding that FDI was cardinal for growth of these countries and therefore need to attract more.

It is noteworthy that few studies in the literature could not support the above findings. Rutaihwa and Simwela (2012), for instance, revealed that the contribution of FDI in mining have been weak and exerting negative pressure on Tanzania's export performance. Mahembe (2014) study also concluded that FDI-led growth hypothesis does not apply to countries in SADC region. According to the study, it is economic growth that drives FDI inflows into the SADC region, and not vice versa. More recent evidence from Adu (2013) who studied the impact of FDI in the mining sector on rural poverty in Ghana for the case of Ghana could not validate the findings of this study. The study attributed such findings to factors-related weak institutional capacity in the country and the ineffective and corrupt mining support institutions. Interestingly, FDI in the non-mining sector is also observed to have a positive and significant impact on the growth on the Zimbabwean economy. The estimated elasticity of output stands at 0.3 which means that $1 \%$ increase on such FDI has increased GDP by $0.3 \%$. Although comparatively slightly lower than mining FDI, non-mining FDI remains an important driver of growth for the country. As such, domestic investment level $(K)$ has a significant relationship with GDP growth in the long run and its coefficient of estimation of 0.46 suggests its relatively important influence on the economy. This conclusion corroborates with the work of Pessoa (2007) and Bakari (2017). Since investment is the act of committing capital into the circular flow of income, this variable is consistent with respect to the economic theory.

The other variables in the model are also reported to have good explanatory power of the country's growth. Education is shown to have been the most important ingredient of economic progress during the last decades at witnessed by its relatively higher output elasticity coefficient. Majeed and Ahmed (2008), Berger and Diez (2008), Hill (2011), Khan (2011), Dutta and Osei-Yeboah (2010) also validated such results in their empirical works and highlighted the crucial importance of education and human capital in the growth process. On the other hand, the openness level (OL) was found to be statistically insignificant with respect to GDP growth. Such a non-significant impact related to the fact that Zimbabwe trade with other nations has not been flourishing as one would have wished, especially given the political turmoil in some of the years. Brima (2015), Manteli (2015) and more recently Khobai et al. (2018) yet reported similar results. Corruption in Zimbabwe could be another factor that could explain why openness did not impact on growth (Muzurura 2016). Financial development is shown to be a significant ingredient of growth for the country, although to a relatively lower extent as compared to the domestic and foreign investment. Such results are in line with Seetanah (2008) and recent work from Guru and Yadav (2019).

The presence of cointegration in our hypothesized model also enables the estimation of the short-run estimates which are summarized in Table 3.

Results from the short-run estimates suggest that FDI in the mining industry (fdim) demonstrated significance in the short run, suggesting that it has a positive and significant effect on the country's output even in the short run, albeit with a relatively 
Table 3 Unrestricted error correction model (ECM): short-run coefficients (dep variable: y)

\begin{tabular}{lcc}
\hline Variables & Coef & $T$ values \\
\hline$\Delta \mathrm{y}_{t-1}$ & $-0.734^{*}$ & 1.87 \\
$\Delta \mathrm{fdim}_{t}$ & $0.166^{* * *}$ & 2.323 \\
$\Delta \mathrm{fdinm}_{t}$ & $0.134^{* *}$ & 1.94 \\
$\Delta \mathrm{I}_{t}$ & -0.966 & -1.12 \\
$\Delta \mathrm{ol}_{t}$ & -0.123 & 0.843 \\
$\Delta \mathrm{k}_{t}$ & $0.115^{* * *}$ & 2.454 \\
$\Delta \mathrm{fd}_{t}$ & $0.065^{*}$ & 1.795 \\
ect & $-0.256^{* * *}$ & 2.244 \\
Const & -0.199 & 1.245 \\
\hline
\end{tabular}

impact. In fact, the variable coefficient is smaller in the short term than in the long term, implying that FDI in the mining sector takes some time for its full impact to ripple through the economy. Similar results are recorded for the case of non-mining FDI as well as domestic investment. While financial development is reported to have a relatively smaller growth effect in the short run, openness and education are confirmed to have no impact in the short run and would imply that they are growth enhancing only in the long run. For instance, there have been numerous studies validating that education has growth impacts only in the long run (see Seetanah 2009 among others).

The term ect $(-1)$ in the table represents the one period lag error of ECM as explained previously. This term directs the macroeconomic variables to reinstate back to original equilibrium position. In other words, it corrects the disequilibrium of the model. Since the coefficient have a negative sign and is significant, it corroborates that there exists a long-run equilibrium relation among all economic variables. It must be noted that the previous year's equilibrium errors will be corrected at the speed of adjustment of $25.6 \%$.

\subsection{Recursive residual testing}

The goodness of fit for the ARDL specification is inspected via stability test. Pesaran et al. (2000) advocates that both CUSUM (cumulative sum of recursive residuals) and CUSUMQ (cumulative sum squares of recursive residuals), developed by Brown et al. (1975), are suitable in checking stability of parameters. The plot of both CUSUM and CUSUMQ is significant at $5 \%$ significance level indicating the parameter or variance stability. The plot of CUSUM test below shows that the residuals are within the red extreme lines, implying that the model is stable. The plot of CUSUMQ confirms this finding as the test shows that the residuals are contained in the two polar bonds (Fig. 1).

\section{Conclusions}

This paper centered on the effects of foreign direct investment in the mining sector on GDP of the Zimbabwean economy. Our econometric model is grounded from an augmented Cobb Douglas model of growth, with capital being segregated into domestic and FDI and subsequently FDI was further decoupled in mining and non-mining FDI. Using time series data for the period 1988-2018, unit root test revealed the existence of a mixture of $I(0)$ and (1) data series and a subsequent test for cointegration 

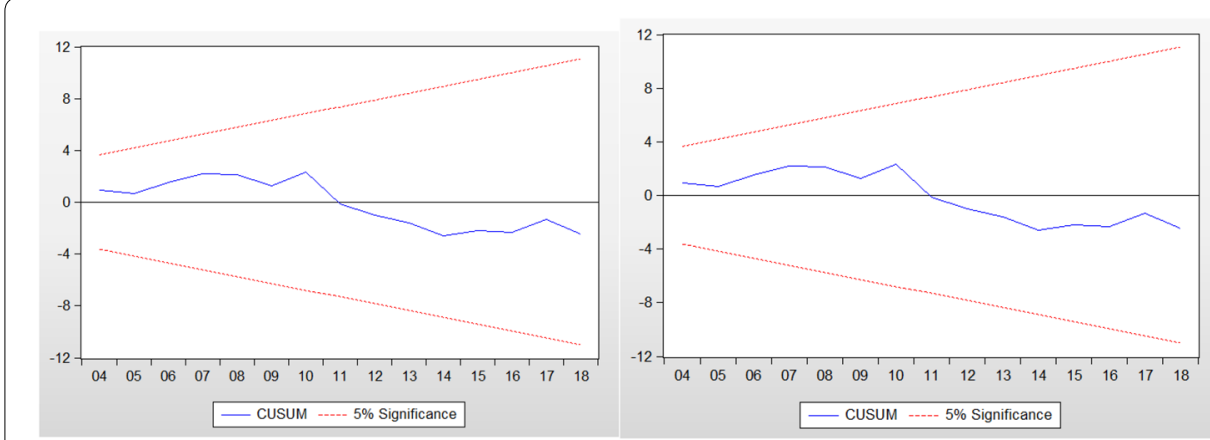

Fig. 1 Plot of cumulative sum of recursive residuals

validated the presence of cointegration. Using an ARDL approach, mining FDI was found to have a significant impact of growth in the long run, relatively higher effects as compared to FDI in non-mining sector and domestic investment. The short-run analysis found that mining FDI as well as non-mining and domestic investment still has positive and significant impacts on growth but at a relatively lower extent. This implies that it takes some time for these investments to have their full effect on the economy. The Zimbabwean government should, apart from creating policies and enhancing the economic and business facilitation climate to further attract FDI, come up with policies and strategies that encourage domestic investment and financial sector development as well as related to trade liberalization since they are also growth conducive.

\section{Acknowledgements}

I appreciate the support and inspiration I was given by Associate Professors Boopenra Seetanah, MuchuwaToddy and Vimbiso Chemugarira.

\section{Authors' contributions}

This paper is part of a PhD thesis by PG, (first author) supervised by BS (second author) who helped significantly in addressing the comments from the reviewer that brought changes to the revised paper. Both authors read and approved the final manuscript.

\section{Funding}

This study is self-funded as it is part of a PhD thesis with Open University of Mauritius.

This funding was provided by Plaxedes Gochero.

\section{Availability of data and materials}

Data generated or analyzed during this study are included in this published article and an appendix also attached.

Ethics approval and consent to participate

All the participants that helped in this study did so willingly.

Consent for publication

The authors agreed to have this paper published.

Competing interests

The authors declare no conflict of interest regarding the publication of this paper.

\section{Author details}

${ }^{1}$ Open University of Mauritius, Reduit, Moka, Mauritius. ${ }^{2}$ University of Mauritius, Reduit, Moka, Mauritius.

\section{Appendix}

See Figs. 2. 


\section{Zimbabwe}

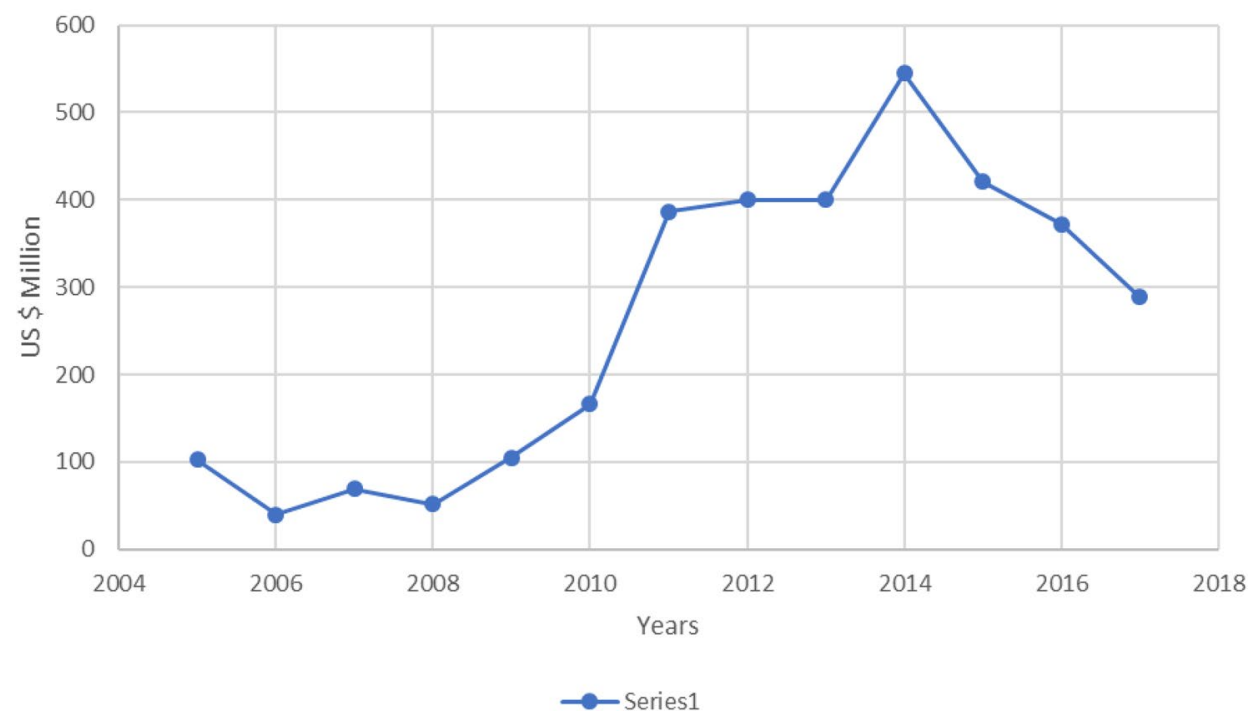

Fig. 2 FDI US\$ Millions for Zimbabwe (2005-2017). Source: Author based on the UNCTAD World Investment Report figures of 2018

Received: 24 January 2019 Revised: 19 March 2020 Accepted: 19 September 2020

Published online: 10 October 2020

\section{References}

Adu G, Mabuah G (2013) Mensah JT (2013) Financial development and economic growth in Ghana: does the measure of financial development matter? Rev Dev Fin 3:192-203

Alfaro L (2017) Gains from foreign direct investment: macro and micro approaches. World Bank Econ Rev 30(Suppl 1):S2-S15

Alfaro L, Chauvin J (2016) Foreign direct investment, finance, and economic development. Encyclopedia of international economics and global trade.

Alfaro LS, Kalemli-Ozcan S, Volosovych V (2007) Capital flows in in a globalized world: the role of policies and institutions. In: Sebastian Edwards E (ed) Capital controls and capital flows in emerging economies: policies, practices and consequences. University of Chicago Press, Chicago

Arcand JL, Berkes E, Panizza U (2015) Too much finance? J Econ Growth 20:105-148

Awolusi OD, Adeyeye OP (2016) Impact of foreign direct investment on economic growth in Africa. Probl Perspect Manag 14(2-2):289-297. https://doi.org/10.21511/ppm.14(2-2).2016.04

Bakari S (2017) The impact of domestic investment on economic growth: new evidence from Malaysia, MPRA Paper No. 79436, posted 30 May 2017 04:34 UTC.

Berger M, Diez JR (2008) Can host innovation systems in late industrializing countries benefit from the presence of transnational corporations? Insights from Thailand's manufacturing industry. Eur Plan Stud 16(8):1047-1074

Beugelsdijk S, Smeets R, Zwinkels R (2008) The Impact of Horizontal and Vertical FDI on Host's Country Economic Growth. Int Bus Rev 17(4):452-472

Brima A (2015) Calls for reform in Sierra Leone's justice system. https://www.insightonconflict.org/blog/2015/10/calls -reform-sierra-leones-justice-system/.

Brown RL et al (1975) Techniques for Testing the Constancy of Regression Relationships over Time. J Roy Stat Soc: Ser B (Methodol) 37(2):149-192

Bucaj A (2018) The impact of FDI in mining on Kosovo's economic growth. Int J Acad Res Bus Soc Sci 8(1):266-292 Burange LG, Ranadive R, Karnik N (2019) Trade openness and economic growth nexus: a case study of BRICS. Foreign Trade Rev 54:1-15

Chamber of Mines of South Africa. (2009) Annual report

Chimuka L (2007) Murowa, Kimberlite Field, University of Zimbabwe Summer Symposium. Harare, University of Zimbabwe Publications

Copeland BR, Taylor MS (1994) North-South trade and the environment. Quart J Econ 109(1994):755-787

Copeland BR, Taylor MS (2003) Trade and the Environment: Theory and Evidence. Princeton University Press, Princeton 
Creane S, Goyal R, Mobarak M, Sab R (2003) Financial development and economic growth in the middle East and North Africa. Newslett Econ Res Forum Arab Countries Iran Turkey 10(2):12-14

Demirhan E, Masca M (2008) Determinants of foreign direct investment flows; Prague economic papers. University of Economics, Prague

Demissie M (2015) FDI, Human capital and economic growth panel data analysis of developing countries. Department of Economics, Sodertorn University, Huddinge

Djokoto JG, Dzeha GC (2012) Determinants and effects of foreign direct investment in Ghana-review of literature. The International Institute for Science, Technology and Education, (IISTE) Vol 2, No 11/12 (2012)

Dollar D (1992) Outward-oriented developing economies really do grow more rapidly: evidence from 95 LDCs, 1976-1985. Econ Dev Cult Change 40(3):523-544

Dunning JH (1993) Multinational Enterprise in the Global Economy. Addison Wesley Publishing Co., Wokingham, England

Dunning JH, Lundan SM (2008) Multinational enterprises and the global economy, 2nd edn. Edward Elgar, Cheltenham, pp 295-296

Dutta N, Osei-Yeboah K (2010) Foreign Direct Investment and Human Capital: The Role of Political and Civil Rights. J Int Dev. available at SSRN: http://ssrn.com/abstract=1263038. Accessed 3 May 2015

Fasanya I (2012) Capital Flows-Growth Nexus in Nigeria: Has Foreign Direct Investment Played a Role in Accelerating Economic Growth? I Sustainable Dev Afr 14:34-52

Fauzel S, Seetanah B, Sannassee RV (2017) Analysing the impact of tourism foreign directinvestment on economic growth: evidence from a small Island developing state. Tourism Economics 23(5):1042-1055

Ford T, Rork J, Elmslie B (2008) Foreign direct investment, economic growth, and the human capital threshold: evidence from US states. Rev Int Econ 16(1):96-113

Fortainer F (2003) Foreign direct investment and host country economic growth: Does the investor's country of origin play a role?

Guru K, Yadav B, Sekhar I (2019) Financial development and economic growth: panel evidence from BRICS. J Econ Fin Admin Sci 24(47). SSRN: https://ssrn.com/abstract=3399728

Government of Zimbabwe (2017) Economic Outlook. Ministry of Macroeconomic Planning and Investment Promotion, Harare

Heliso OS (2014) The impact of foreign direct investment on exports in COMESA countries. The Department of Economics, Ottawa University, Ottawa

Helphman E, Grossman GM (1991) Innovation and Growth in the Global Economy. MIT Press, Cambridge, MA

Hill CWL (2011) International business completing in the global marketplace. McGraw-Hill, New York

Hong L (2014) Does and how does FDI promote the economic growth? Evidence from dynamic panel data of prefecture city in China. IERI Procedia 6:57-62. https://doi.org/10.1016/j.ieri.2014.03.010

Ipek ÖK (2015) The contribution Of FDI flows to domestic investment: an econometric analysis of developing countries. Celal Bayar Üniversitesi, II.I.B.F. MANiSA

Javorcik BS (2004) Does foreign direct investment increase the productivity of domestic firms? Search of Spillovers through Backward Linkages. Am Econ Rev 2:44-56

Khadaroo J, Seetanah B (2008) Transport and economic performance: the case of Mauritius. J Transp Econ Policy 42:255-267

Khadaroo AJ, Seetanah B (2009) The Role of transport infrastructure in FDI: Evidence from Africa using GMM Estimates. J Transp Econ Policy 43(3):365-384

Khaliq A, Noy I (2007) Foreign direct investment and economic growth: empirical evidence from sectoral data in Indonesia. https://www.economics.hawaii.edu/research/workingpapers/WP_07-26.pdf.

Khan MA (2007) Foreign Direct Investment and Economic Growth: The Role of Domestic Financial Sector. PIDE 2007:18

Khan MA (2011) Foreign direct investment and economic growth in Pakistan: a sectoral analysis. PIDE Re PEC 2011:67

Khobai H, Kolisi N, Moyo C (2018) The Relationship Between Trade Openness and Economic Growth: The Case of Ghana and Nigeria. Int J Econ Fin Issues. 8:77

King RG, Levine R (1993) Finance and growth: schumpeter might be right. Quart J Econ CVIII:717-738

Knoerich J (2017) How does outward foreign direct investment contribute to economic development in less advanced home countries? Oxf Dev Stud J 94(3):605-627

Koojaroenprasit S (2012) The impact of foreign direct investment on economic growth: a case study of South Korea. Int J Bus Soc Sci 3:8-19

Kurtishi-Kastrati S (2013) The effects of foreign direct investments for host country's economy. Eur J Interdiscip Stud 5: 26-38.45, 2017, Issue 4.

Levine R et al (2000) Financial intermediation and growth: Causality and causes. Journal of Monetary Economics 46(1):31-77

Mahembe E (2014) Foreign Direct Investment Inflows and Economic Growth in SADC Countries - A Panel Data Approach. University of South Africa, Pretoria

Maliwa EA, Nyambe JM (2015) Investigating the impact of FDI on economic growth in Zambia: 1980-2012. Eur J Bus Econ Account 3(3):41-50

Majeed MT, Ahmad E (2008) Human Capital Development and FDI in Developing Countries. J Econ Cooperation 29(3):79-104

Manteli A (2015) Does Trade Openness Cause Growth? An Empirical Investigation. Master Thesis, Department of Economics, Södertörns University

McKinnon RI (1973) Money and capital in economic development. Brookings Institution, Washington, DC

Melnyk L, Kubatko O, Pysarenko S (2014) The impact of foreign direct investment on economic growth: case of communism post-transition economies. Probl Perspect Manag 12(1):17-24

Mencinger J (2008) Direct and indirect effects of FDI on current account. University of Ljubljana, Ljubljana

Moura R, Forte R (2010) The Effects of Foreign Direct Investment on Host Country Economic Growth-Theory and Empirical Evidence. FEP 390, Universidade do Porto, Faculdade de Economia do Porto. 
Moura R, Forte R (2013) The effects of foreign direct investment on the host country economic growth—-theory and empirical evidence, FEP. University of Porto, Porto

Moyo T (2013) The impact of foreign direct investment on economic growth: the case of Zimbabwe (2009-2012). Int J Econ Fin Manag Sci 1:323-329

Muntah S, Khan M, Haider N, Ahmad A (2015) Impact of foreign direct investment on economic growth of Pakistan. Am Res J Bus Manag 1(1):190-202

Muzurura J (2016) Determinants of foreign direct investment (FDI) in Zimbabwe: What factors matter? University Library of Munich, Germany

Nkoro E, Uko AK (2016) Autoregressive Distributed Lag (ARDL) cointegration technique: application and interpretation. J Stat Econ Methods 5(4):63-91

Noormamode S (2008) Impact of Foreign Direct Investment on Economic Growth: Do Host Country Social and Economic Conditions Matter? University of Neuchatel, Switzerland

Noy I, Vu TB (2007) Capital Account Liberalisation and FDI. N Am J Econ Fin 18(2):175-194

Organisation for Economic Co-Operation and Development, OECD (2002) OECD publications service, 2, rue AndréPascal, 75775 Paris, Cedex 16, France.

Pesaran MH et al (2000) Structural analysis of vector error correction models with exogenous I(1) variables. J Econ 97:293-343

Pessoa A (2007) FDI and host country productivity: a review. Working Paper da Faculdade de Economia da Universidade do Porto $n^{\circ} 251$

Porter ME, van de Linde C (1995) Toward a new conception of the environment-competitiveness relationship. J Econ Perspect 9:997-998

Rajan RG, Zingales L (1998) Financial dependence and growth. Am Econ Rev 88:559-586

Rugraff E, Hansen MW (2011) Multinational corporations and local firms in emerging economies. Amsterdam University Press, Amsterdam

Ruranga C, Ocaya B, Kaberuka W (2013) Foreign direct investment and economic growth in Rwanda: a time series analysis. J Bus Manag Corp Affairs 2(1):11-18

Rutaihwa J, Simwela A (2012) Econometric analysis of FDI in the mining sector to Tanzania's export capacity. Int J Acad Res Bus Soc Sci 2(10):174-191

Sachs G, Warner T (1995) Natural resource abundance and economic growth. NBER Working Paper No. 5398.

Salvatore D (2007) International Economics. Prentice-Hall, Upper Saddle River

Samargandi N, Fidrmuc J, Ghosh S (2015) Is the relationship between financial development and economic growth monotonic? Evidence from a sample of middle-income countries. World Dev 68:66-81

Sandu S, Ciocanel B (2014) Impact of R\&D and Innovation on high-tech export. Procedia Econ Finan 15:80-90

Seetanah B (2008) Financial development and economic growth in an ARDL approach. Applied Economics Letter 4(43): $43-50$

Seetanah B (2009) The economic importance of education: evidence from Africa using dynamic panel data analysis. J Appl Econ 12(1):137-157

Seetanah B, Teeroovengadum V (2019) Does higher education matter in African economic growth? Evidence from a PVAR approach. Policy Rev High Educ 3:125-143. https://doi.org/10.1080/23322969.2019.1610977

Seetanah B, Ramessur ST, Rojid S (2009) Financial development and economic growth: new evidence from a sample of Island economies. J Econ Stud 36(2):124-134

Solomon EM (2011)Foreign Direct investment, host country factors and economic growth. Ensayos Revista de Economia $\mathrm{xxx}(1): 41-70$

UNCTAD (2009) World Investment Report 2009 (1). United Nations, New York and Geneva

UNMillennium Development Goals Report (2015)https://www.un.org/millenniumgoals/2015

Vu TB, Gangnes B, Noy I (2006) Is foreign direct investment good for growth? Answers using sectoral data from China and Vietnam. Unpublished

World Bank (2017) How developing countries can get the most out of direct investment. World Bank, Washington DC World Economic Forum (2013) Is foreign direct investment responsible for boom and bust cycles? Reports published June 2013.

World Investment Report (2017) https://unctad.org/en/Docs/wir2017_en.pdf

Zekarias SM (2016) The impact of foreign direct investment (FDI) on economic growth in Eastern Africa: evidence from panel data analysis. Appl Econ Fin 3(1):145-160

Zilinske A (2010) Negative and positive effects of foreign direct investment. Econ Manag 15:E332-E336

\section{Publisher's Note}

Springer Nature remains neutral with regard to jurisdictional claims in published maps and institutional affiliations. 